\title{
UPAYA PENINGKATAN HASIL BELAJAR MATEMATIKA SISWA DENGAN PEMBELAJARAN KOOPERATIF TIPE STUDENT TEAM ACHIEVEMENT DIVISION (STAD) DI KELAS VII SMP NEGERI 11 KOTA BENGKULU
}

\author{
${ }^{1}$ Fiki Puspita Sari, ${ }^{2}$ Syafdi Maizora, ${ }^{2}$ Dewi Herawaty \\ ${ }^{1,2}$ Program Studi Pendidikan Matematika JPMIPA FKIP Universitas Bengkulu \\ email : ${ }^{1}$ puspitasarifiki@gmail.com, ${ }^{2}$ syafdiichiemaizora@unib.ac.id
}

\begin{abstract}
Abstrak
Penelitian ini bertujuan untuk mengetahui cara meningkatkan hasil belajar siswa pada materi bangun datar segiempat dan segitiga. Jenis penelitian yang dilaksanakan adalah Penelitian Tindakan Kelas (PTK) dengan teknik pengumpulan data melalui tes hasil belajar. Subyek dalam penelitian ini adalah siswa kelas VII C SMP Negeri 11 Kota Bengkulu. Hasil penelitian ini menunjukkan bahwa penerapan pembelajaran kooperatif tipe STAD dapat meningkatkan hasil belajar siswa. Hasil belajar dapat ditingkatkan dengan cara membuat pertanyaan-pertanyaan yang lebih sederhana pada LKPD, memberikan penjelasan singkat tentang istilah-istilah yang belum dipahami siswa, memberikan motivasi dan apersepsi, serta memberikan penghargaan kepada kelompok terbaik. Peningkatan hasil belajar siswa dapat dilihat dari peningkatan nilai rata-rata siswa dari siklus I hingga siklus III yaitu : 72,$82 ; 81,24,83,88$ dengan presentase ketuntasan belajar klasikal dari siklus I hingga siklus III yaitu: $55,88 \% ; 70,59 \% ; 82,35 \%$.
\end{abstract}

kata kunci: pembelajaran kooperatif, Student Team Achievement Division (STAD) dan hasil belajar siswa.

This study aimed to find out how to improve students' learning outcomes on the twodimentional figure quadrilateral and triangle. the research design was Classroom Action Research (CAR). Instrumen data collecting used observation sheet and test. The subject in this study was students of class VII C SMP Negeri 11 Kota Bengkulu. Enhanced results can be improved by learning how to make the questions more simply at LKPD, provide a brief explanation of the terms that are not yet understood, give students the motivation and apersepsi, as well as giving the prize to the best group. The improvement of students' learning outcomes can be seen from the improvment of the average score of students from cycle I to cycle III that were: 72.82; 81,24, 83,88 with the completion percentage of classical learning from cycle I to cycle III that were: 55,88\%; 70.59\%; $82.35 \%$.

keywords: cooperative learning , Student Team Achievement Division (STAD) and student' learning outcomes.

\section{PENDAHULUAN}

Pelaksanaan proses pembelajaran di sekolah pada umumnya belum memenuhi tuntutan bangsa. Di sekolah-sekolah pada umumnya masih banyak guru yang menerapkan pembelajaran konvensional. Padahal pada penerapan model pembelajaran tersebut siswa menjadi pihak yang pasif dan hanya menerima informasi yang diberikan guru. Banyak siswa yang menjadi semakin malas untuk belajar dan mengakibatkan hasil belajar mereka menjadi rendah.
Berdasarkan hasil wawancara dengan guru SMP Negeri 11 kota Bengkulu pada hari Kamis, 26 Januari 2017, beliau menyatakan bahwa masalah yang dihadapi dalam proses belajar mengajar matematika di kelas VII C SMP Negeri 11 Kota Bengkulu antara lain: 1) siswa menganggap matematika sebagai mata pelajaran yang paling sulit untuk dipahami; 2) Selama ini hasil ujian matematika masih rendah dibanding dengan mata pelajaran lain; 3) Siswa membutuhkan waktu yang lama 
untuk dapat memahami materi yang disampaikan guru; 4) Kurangnya semangat siswa untuk menyelesaikan soal-soal yang diberikan. Tabel berikut Menyajikan data hasil ulangan harian matematika terakhir siswa kelas VII C SMP Negeri 11 Kota Bengkulu.

Tabel 1. Nilai Ulangan Semester Ganjil 2016/2017

\begin{tabular}{|c|c|c|}
\hline Data & Nilai & Jumlah \\
\hline $\begin{array}{c}\text { Nilai } \\
\text { Tertinggi }\end{array}$ & 82 & 1 siswa \\
\hline $\begin{array}{c}\text { Nilai } \\
\text { Terendah }\end{array}$ & 46 & 1 siswa \\
\hline $\begin{array}{c}\text { Kurang dari } \\
\text { KKM }\end{array}$ & $<75$ & 26 siswa \\
\hline Rata-rata & \multicolumn{3}{|c|}{65,83} \\
\hline
\end{tabular}

(Sumber: Guru Matematika SMP Negeri 11 Kota Bengkulu)

Untuk mengatasi beberapa permasalahan dalam proses belajar mengajar matematika maka guru ditutut untuk menggunakan model pembelajaran yang sesuai dengan tujuan pembelajaran. Salah satu model pembelajaran yang dapat digunakan yaitu penerapkan pembelajaran kooperatif tipe Student Team Achievement Division (STAD). Dalam pembelajaran kooperatif tipe Student Team Achievement Division (STAD) siswa dilatih untuk aktif dalam kegiatan pembelajaran. Pada pelaksanaannya, siswa melakukan diskusi dengan anggota kelompoknya untuk menyelesaikan LKPD yang diberikan guru sebagai bahan diskusi kelompok. Hal lain yang diharapkan dapat menarik perhatian siswa pada model pembelajaran ini adalah adanya penghargaan untuk kelompok terbaik dari suatu kelas. Dengan diberikannya penghargaan maka hal tersebut dapat meningkatkan semangat belajar siswa untuk lebih serius belajar sehingga hasil belajar mereka dapat meningkat.

\section{METODE}

\section{Rancangan Penelitian}

Penelitian jenis PTK dipilih karena dianggap paling sesuai untuk pelaksanaan pembelajaran matematika dan sesuai dengan minat peneliti sendiri.

2. Sasaran Penelitian

Penelitian ini dilaksanakan di SMP Negeri 11 Kota Bengkulu yang terletak di provinsi Bengkulu. Subyek penelitian ini adalah siswa kelas VII C SMP Negeri 11 Kota Bengkulu tahun ajaran 2016/2017 dengan jumlah siswa 34 orang, yang terdiri dari 19 orang siswa dan 15 orang siswi. Kelas VII C dipilih sebagai subjek penelitian karena persentase hasil belajarnya masih rendah. Dari data hasil ulangan semester ganjil 2016/2017 diketahui bahwa nilai rara-rata kelas belum memenuhi kriteria ketuntasan minimal (KKM) yaitu 75. Adapun nilai rata-rata kelas VII C SMP Negeri 11 Kota Bengkulu tersebut yaitu 65,83. Dari nilai rata-rata kelas terlihat bahwa kelas VII C mewakili kemampuan yang heterogen sehingga diharapkan penelitian ini dapat mewakili keseluruhan populasi. Peneliti berharap penerapan pembelajaran kooperatif tipa STAD dapat meningkatkan aktivitas dan hasil belajar matematika siswa kelas VII $\mathrm{C}$ sehingga semua siswa dapat mencapai nilai di atas kriteria ketuntasan minimal (KKM).

3. Teknik Pengumpulan Data

Teknik pengumpulan data yang digunakan dalam penelitian ini adalah tes hasil belajar. Tes hasil belajar dilakukan pada setiap akhir siklus. Soal tes berisi materi-materi yang telah dirangkum sesuai materi yang telah dipelajari. Tes dilakukan untuk mengetahui peningkatan hasil hasil belajar siswa stelah diterapkannya pembelajaran kooperatif tipe Student Team Achievement Division (STAD).

4. Teknik Analisis Data

Suatu kelas dapat dinyatakan tuntas belajarnya apabila dalam kelas tersebut terdapat $\geq 80 \%$ siswa yang memperoleh nilai di atas kriteria ketuntasan minimal (KKM) yang ditetapkan sekolah SMP Negeri 11 Kota Bengkulu yaitu 75 .

5. Indikator Keberhasilan

Penelitian akan dihentikan apabila telah mencapai indikator keberhasilan. Indikator keberhasilan adalah batas maksimal pelaksanaan PTK (Jalil, 2014: 32). Adapun indikator keberhasilan tindakan dalam penelitian ini adalah apabila $\geq 80 \%$ siswa mencapai kriteria ketuntasan minimal (KKM) yang ditetapkan sekolah yaitu 75 . 


\section{HASIL DAN PEMBAHASAN}

\section{Hasil Penelitian}

Berdasarkan pembelajaran yang dilaksanakan secara keseluruhan dimulai dari siklus I hingga siklus III menunjukkan peningkatan hasil belajar siswa secara signifikan. Hasil penelitian menunjukkan bahwa Penerapan Model Pembelajaran kooperatif tipe Student Team Achievement Division (STAD) dapat meningkatkan hasil belajar matematika siswa.

Data sebelum diberikan tindakan menunjukkan bahwa hasil belajar siswa masih rendah atau belum memenuhi kriteria ketuntasan minimal (KKM) yaitu 65,83 dengan kriteria kurang pada aktivitas siswa. Data peningkatan hasil belajar siswa dengan penerapan pembelajaran kooperatif tipe Student Team Achievement Division (STAD) dari siklus I, siklus II dan siklus III menunjukkan peningkatan pada setiap siklusnya. Data hasil siklus I menunjukkan rata-rata hasil belajar siswa sebesar 72,82 dengan ketuntasan klasikal 55,88\%, siklus II sebesar 81,24 dengan ketuntasan klasikal $70,59 \%$, siklus III sebesar 83,88 dengan ketuntasan klasikal 82,35\%.

Peningkatan hasil belajar siswa dikatakan meningkat dilihat dari meningkatnya indikator hasil belajar siswa yang peneliti buat sebelum penelitian dimulai.

\section{Pembahasan}

Pembahasan pada penelitian ini merupakan sesuatu yang berkaitan dengan permasalahan dan tindakan yang terjadi selama penelitian. Indikator yang digunakan sebagai tercapainya peningkatan hasil belajar siswa adalah $\geq 80 \%$ siswamencapai kriteria ketuntasan minimal (KKM) yang ditetapkan sekolah yaitu 75 .

Pada penelitian terdahulu yang dilakukan oleh Lia Puspita Sari (2012) disimpulkan bahwa Penerapan Pembelajaran Cooperatif Tipe Student Team Achievement Division (STAD) dapat meningkatkan aktivitas dan hasil belajar siswa dalam proses belajar mengajar. Silvia Cici Yuliza (2013) menyatakan bahwa adanya peningkatan aktivitas dan hasil belajar siswa dalam proses belajar mengajar setelah diterapkanya Model Pembelajaran Problem Posing Tipe Post Solution Posing melalui pembelajaran kooperatip tipe STAD. Een Junvefty (2014) mnyimpulkan bahwa adanya peningkatan aktivitas dan hasil belajar matematika siswa seteah diterapkannya model pembelajaran Kooperatif Tipe Student Team Achievement Division (STAD). Anggi Meifriawan (2015) menyimpulkan adanya peningkatan aktivitas dan hasil belajar dalam proses pembelajaran setelah diterapkanya model Pembelajaran Student Team Achievement Division (STAD).

Berdasarkan penelitian terdahulu tersebut, terdapat beberapa perbedaan dengan penelitian yang dilakukan oleh peneliti. Perbedaannya yaitu LKPD yang dibuat oleh peneliti dibuat lebih sederhana dari LKPD peneliti terdahulu dan media pembelajaran yang digunakan peneliti lebih mudah ditemukan di dalam ruang kelas sehingga waktunya lebih efisien.

Hasil belajar matematika siswa sebelum dilaksanakan tindakan kelas masih rendah terbukti nilai rata-rata hasil belajar siswa sebesar 65,83 yang menunjukkan nilai dibawah kriteria ketuntasan minimal (KKM). Tindakan yang digunakan untuk meningkatkan hasil belajar siswa adalah Penerapan Pembelajaran Kooperatif Tipe Student Team Achievement Division (STAD) pada materi segiempat dan segitiga.

Pada siklus I hasil belajar siswa sudah mulai terlihat mengalami peningkatan dibandingkan dengan sebelum pelaksanaan tindakan. Evaluasi hasil tes siklus siswa pada siklus I menjadi landasaPn perbaikanperbaikan yang dilaksanakan pada siklus II. Pada siklus II hasil belajar siswa menunjukkan peningkatan dibanding siklus I, meskipun hasil belajar siswa yang belum memenuhi ketuntasan klasikal. Evaluasi hasil tes siklus II menjadi landasan perbaikan-perbaikan yang dilaksanakan pada siklus III. Pada siklus III indikator aktivitas dan hasil belajar siswa sudah memenuhi indikator aktivitas dan hasil belajar siswa yaitu pada kisaran 21,66 $\leq$ $x<27$ untuk sembilan butir pengamatan aktivitas dan nilai $\geq 75,00$ dengan 
ketuntasan klasikal minimal $\geq 80 \%$ adalah indikator yang digunakan sebagai tercapainya hasil belajar siswa. oleh karenanya penelitian dihentikan sampai siklus III.

Berdasarkan hasil peneltian tersebut, menunjukkan bahwa penerapan model pembelajaran kooperatif tipe Student Team Achievement Division (STAD) dapat meningkatkan hasil belajar siswa pada materi segiempat dan segitiga di kelas VII SMP Negeri 11 Kota Bengkulu.

\section{PENUTUP \\ Simpulan}

Berdasarkan penelitian yang telah dilaksanakan di kelas VII C SMP Negeri 11 Kota Bengkulu dapat disimpulkan bahwa penerapan pembelajaran kooperatif tipe Student Team Achievement Division (STAD) dapat meningkatkan hasil belajar matematika siswa dengan cara :

a. Guru memberikan LKPD sebagai bahan diskusi kelompok yang bertujuan untuk menuntaskan hasil belajar siswa pada materi yang sedang dipelajari.

b. Guru membuat pertanyaan-pertanyaan yang lebih sederhana pada LKPD agar siswa lebih memahami apa yang harus dikerjakan;

c. Guru memberikan penjelasan singkat tentang istilah-istilah yang berhubungan dengan materi segiempat dan segitiga yang belum dipahami siswa;

d. Guru memberikan motivasi dan bimbingan lebih pada siswa yang mengalami kesulitan pada materi yang sedang dipelajari;

e. Guru memberikan penghargaan kepada kelompok terbaik berdasarkan poin perkembangan untuk memotivasi siswa memahami materi yang dipelajari.

Hal tersebut terbukti dapat meningkatkan hasil belajar siswa dari siklus I sampai siklus III. Analisis tes siklus I menunjukkan nilai ratarata siswa 72,82 dengan ketuntasan belajar klasikal 55,88\%, kemudian pada siklus II hasil belajar meningkat dengan nilai rata-rata siswa 81,24 dengan ketuntasan belajar klasikal
70,59\%. Peningkatan juga terjadi pada siklus III dengan nilai rata-rata siswa 83,88 dengan ketuntasan belajar klasikal $82,35 \%$.

\section{Saran}

Berdasarkan penelitian yang telah dilakukan maka peneliti memberikan beberapa saran, yaitu :

a. Buatlah catatan kecil untuk soal yang menggunkan istilah yang belum dipahami siswa;

b. Sebelum materi disampaikan pastikan untuk memberi apersepsi dengan cukup agar siswa lebih mudah memahami materi yang akan dipelajari;

c. Guru harus secermat mungkin membagi kelompok agar diskusi berjalan dengan baik;

d. Guru harus lebih kreatif dalam membuat LKPD agar siswa tertarik untuk mengerjakannya.

\section{DAFTAR PUSTAKA}

Arikunto, Suharsimi, dkk. 2012. Penelitian Tindakan Kelas. Jakarta: Bumi Aksara.

Aunurrahman. 2013. Belajar dan Pembelajaran. Bandung: Alfabeta.

Adinawan, Cholik dan Sugijono. 2014. Matematika SMP/ MTs Jilid 1 Kelas VII. Erlangga.

Barnett Rich. 2005. Geometri. Jakarta: Erlangga

Hamzah, Ali. 2014. Evaluasi Pembelajaran Matematika. Jakarta: PT RajaGrafindo Persada.

Herawaty, Dewi, dkk. 2007. Aturan Penulisan K I, Metodologi Penelitian, Pengembangan, dan PTK. Bengkulu: Universitas Muhammadiyah Bengkulu.

Junvefty, Een. 2014. Penerapan Model Pembelajaran Tipe Student Teams Achievement (STAD) pada siswa kelas VIII SMP Negeri 8 Kota Bengkulu. Skripsi Strata 1 Pendidikan Matematika Universitas Bengkulu (Tidak Dipublikasikan).

Meifriawan, Anggi. 2015. Penerapan Model Pembelajaran Student Teams Achievement Division (STAD) Dalam Meningkatkan AKTIVITAS Dan Hasil 
Belajar Matematika Siswa Kelas VII A SMP Negeri 1 Pondok Kelapa.

Soedijarto.2000.Pendidikan Nasional Sebagai Wahana Mencerdaskan Kehidupan Bangsa. Jakarta: RINI Book Collection

Sari, Lia Puspita. 2012. Penerapan Model Pembelajaran Cooperative Tipe Student Teams Achievement Division (STAD) Dalam Meningkatkan Aktivitas Dan Hasil Belajar Matematika Siswa Kelas VII A SMP Negeri 1 Pondok Kelapa. Skripsi Strata 1 Pendidikan Matematika Universitas Bengkulu (Tidak Dipublikasikan).

Sudjana.2005. Metoda Statistika. Bndung: PT. Tarsito Bandung.

Sudjana, Nana. 2011.Penilaian Hasil Belajar Mengajar. Bandung: PT. Remaja Rosdakarya.
Sudijono, Anas. 2014. Pengantar Statistik Pendidikan. Jakarta: RajaGrafindo Persada.

Slavin, Robert E. 2015. Cooperatif Learning. Bandung: Nusa Media.

Trianto. 2011. Mendesain Model Pembelajaran Inovatif Progresif. Jakarta: Kencana Prenada Media Group

Yuliza, Silvia Cici. 2013. Penerapan Model Pembelajaran Problem Solving Melalui Pembelajaran Kooperatif Tipe STAD untuk Meningkatkan Hasil Belajar Matematika Siswa Kelas VII SMPN 18 Kota Bengkulu. Skripsi Strata 1 Pendidikan Matematika Universitas Bengkulu (Tidak Dipublikasikan. 